Tersedia Online di http://journal.unismuh.ac.id/index.php/otoritas

Otoritas : Jurnal Ilmu Pemerintahan, 6 (2), Oktober 2016, 71-81

\title{
Struktur Organisasi Kelembagaan Penanaman Modal di Kota Bandung
}

\author{
Dewi Gartika*) \\ Badan Penelitian, Pengembangan, dan Penerapan Ilmu Pengetahuan dan Teknologi, \\ Provinsi Jawa Barat, Jalan Citarum No. 8 Bandung, Indonesia
}

Diterima : 10 Juni 2016; Disetujui : 29 Agustus 2016; Dipublikasikan 14 Oktober 2016

\begin{abstract}
In Act No. 23 of 2014 on Regional Government, where there mention of the obligatory functions and affairs of choice, where one obligatory This is an investment, then in Government Regulation No. 38 Year 2007 on the dealings between the central government, provincial government and district / city government, a local government authority is in the field of investment, government Bandung, capital investment is obligatory and one local government authority is placed in the structure organization Bappeda Bandung is in the Investment Sector, is of course contrary to the Law No. 23 Year 2014 and Government Regulation No. 38 of 2007. This paper provides the organizational structure of institutional investment in the city of Bandung.
\end{abstract}

Keywords: structure; organizations; institutions; investment; capital

\begin{abstract}
Abstrak
Dalam Undang-Undang Undang-Undang Nomor 23 Tahun 2014 tentang Pemerintahan Daerah disebutkan mengenai urusan wajib dan urusan pilihan, dimana salah satu urusan wajib ini adalah penanaman modal, kemudian dalam Peraturan Pemerintah Nomor 38 Tahun 2007 tentang Pembagian urusan antara pemerintah pusat, pemerintah provinsi, dan pemerintah kabupaten/kota, salah satu kewenangan pemerintah daerah adalah dalam bidang penanaman modal, di pemerintahan Kota Bandung, penanaman modal yang merupakan urusan wajib dan salah satu kewenangan pemerintah daerah ditempatkan dalam struktur organisasi Bappeda Kota Bandung yaitu pada Bidang Penanaman Modal, ini tentu saja berseberangan dengan UU No. 32 Tahun 2004/UU No. 23 Tahun 2014 dan Peraturan Pemerintah No. 38 Tahun 2007. Artikel ini berisi tentang struktur organisasi kelembagaan penanaman modal di Kota Bandung.
\end{abstract}

Kata kunci : struktur; organisasi; kelembagaan; investasi; modal

Cara Penulisan Sitasi : Gartika, D. (2016). Struktur Organisasi Kelembagaan Penanaman Modal di Kota Bandung. Otoritas : Jurnal Ilmu Pemerintahan, 6(2), 71-81.

${ }^{*}$ Penulis Korespondensi.

E-Mail : dewi61214@gmail.com

Copyright (C) 2016, Otoritas : Jurnal Ilmu Pemerintahan, p-ISSN: 2088-3706, e-ISSN: 2502-9320 
Tersedia Online di http://journal.unismuh.ac.id/index.php/otoritas

Otoritas : Jurnal Ilmu Pemerintahan, 6 (2), Oktober 2016, 72

\section{Pendahuluan}

Struktur memegang peranan yang sangat penting dalam jalannya organisasi. Struktur memungkinkan sebuah organisasi untuk mencapai tujuan. Apapun organisasinya, organisasi selalu didirikan untuk mencapai tujuan. Ada orientasi yang ingin dicapai dengan berdirinya sebuah organisasi dan orientasi tersebut akan lebih mudah dicapai jika terdapat pembagian kerja yang diimplementasikan dalam sebuah struktur. Organisasi adalah pengaturan yang disengaja terhadap sejumlah orang untuk mencapai tujuan tertentu (Robbins dan Coulter, 2004). Tujuan tersebut dapat berupa keuntungan (perusahaan), kebijakan publik (pemerintah) maupun perubahan sosial (organisasi nirlaba). Untuk mencapai tujuan tersebut diperlukan pembagian kerja dan penempatan yang sesuai bagi setiap orang. Untuk mencapai tujuan tersebut, diperlukan sebuah struktur sebagai pengejawantahan strategi organisasi ke dalam pelaksanaannya dilapangan. Maksudnya tidak lain adalah agar tujuan organisasi dapat tercapai dengan efektif dan efisien yaitu dengan membuat sebuah desain struktur yang memiliki fleksibilitas untuk menyesuaikan kondisi yang dinamis dimana semua hal dapat berubah dengan cepat. Untuk itulah diperlukan sebuah struktur formal yang dapat mendukung dan mempermudah anggota organisasi dalam pelaksanaan pekerjaan organisasi. Kegiatan tersebut dapat dikatakan sebagai pengorganisasian yang didefinisikan sebagai proses penciptaan struktur organisasi (Robbins dan Coulter, 2004).

Leach, Stewart, dan Waish (1994) dalam The Changing Organization and Management of Local Government, menjelaskan struktur dari sebuah organisasi adalah pola aturan, posisi, dan peran yang memberikan arah dan koherensi pada strategi dan proses organisasi, dan secara tipikal digambarkan dalam diagram or- ganisasi, deskripsi pekerjaan dan polapola kewenangan (the structure of an organization is the pattern of rules, positions, and roles that give shape and coherence to its strategy and process, and is typically described in organization charts, job descriptions and patterns of authority).

Sebagaimana telah dikaji oleh para peneliti, pola pertama dalam proses perubahan organisasi publik itu terjadi terutama di banyak negara di Eropa dan Amerika Utara. Chrisholm (2000) telah melakukan studi tentang restrukturisasi organisasi pemerintah lokal di Inggris yang menunjukkan adanya kecenderungan itu. Di Amerika Serikat, reformasi birokrasi bermula dari Osborne dan Gaebler (1992) yang menyuntikkan ideide tentang otoritas yang harus didesentralisasikan dari jenjang organisasi pemerintahan tingkat atas kepada jenjang organisasi pemerintahan tingkat bawah. Oakerson(2006) telah melakukan studi tentang restrukturisasi organisasi pemerintah lokal di Amerika Serikat di mana ia melihat adanya dorongan kepada pemerintah-pemerintah lokal untuk secara intensif melakukan perubahan birokrasinya.

Dari segi kajian organisasi, menurut Mintzberg (1979), prosedur top-down dalam pembentukan unit-unit organisasi (unit grouping) dilakukan apabila bermula dari kebutuhankebutuhan umum (misi atau tujuan organisasi yang hendak dicapai) ke pekerjaan-pekerjaan spesifik. Lebih jauh menurut Mintzberg (1979), semakin besar kontrol kekuatan dari luar organisasi, maka semakin terformalisasi struktur organisasi itu dan semakin tersentralisasi atau terkonsentrasi kekuasaan pembuatan keputusan organisasinya. Kondisi seperti itu pada akhirnya akan membentuk organisasi birokratik, yakni suatu organisasi di mana kekuasaan terkonsentrasi pada pemimpin, prosedur membelenggu pegawai sehingga ia tidak dapat 
Tersedia Online di http://journal.unismuh.ac.id/index.php/otoritas

Otoritas : Jurnal Ilmu Pemerintahan, 6 (2), Oktober 2016, 73

mengembangkan kreativitasnya, proses pekerjaan yang terstandarisasi secara rigit - sehingga pekerja tidak mampu berinovasi, komunikasi yang formal, dan pelaporan yang teregulasi secara ketat. Organisasi yang demikian ini memiliki daya adaptasi terhadap perubahan lingkungan yang rendah.

Hall (1977) menyatakan bahwa struktur organisasi mempengaruhi dua hal, yakni perilaku individu dan kinerja organisasi (efisiensi, moral, dan efektivitas). Di Inggris, Chrisholm (2000) melihat bahwa restrukturisasi pemerintah lokal di Inggris juga diarahkan pada "swastanisasi". Menurut Valler, Wood, and North (2000), sejak 1980-an di Inggris restrukturisasi pemerintahan lokal secara analitis harus dikaitkan dengan representasi kepentingan bisnis pada tingkat lokal. Di Canada, Brunet-Jailly (2003) menemukan bahwa kerjasama intermunicipalities membawa manfaat ekonomi yang sangat besar bagi pemerintah-pemerintah lokal. Brunet Jailly dengan begitu juga melihat bahwa model swastanisasi pemerintah lokal dalam kerangka restrukturisasi sangatlah bermanfaat. Di Australia, Dollery dan Crase $(2004,2005)$ mengkaji secara kritis restrukturisasi organisasi pemerintah lokal yang sejauh ini telah diorientasikan pada integrasi terhadap pasar bebas demi mencapai efisiensi dalam pelayanan publik. Namun demikian, pada akhirnya Dollery dan Crase tetap mengakui pentingnya mengorientasikan organisasi pemerintah lokal pada cara-cara swasta dalam proses restrukturisasi organisasi pemerintah lokal itu. Di New Zealand, studi tentang restrukturisasi organisasi pemerintah lokal juga telah dilakukan (McKinlay Douglas Limited, 2006). Dalam hal ini, mereka mengkaji mengenai restrukturisasi organisasi pemerintah lokal di New Zealand yang kemudian menyarankan pentingnya swastanisasi dan efisiensi. Sementara itu di negaranegara berkembang, studi-studi empiris tentang restrukturisasi organisasi pemerintah daerah juga telah dilakukan. Dalam hal ini, reformasi organisasi pemerintahan lokal diarahkan bagi peran organisasi swasta dan institusiinstitusi non pemerintahan untuk mengambil alih fungsi-fungsi pemerintahan sebanyak mungkin (Dhungel, 1996).

Di Indonesia, dalam perwujudan sebuah organisasi birokrasi yang efektif dan efisien seperti menuju good governance yang diidam-idamkan oleh semua pihak selama ini, pemerintah melakukan perbaikan di tubuh birokrasi dengan beberapa cara. Salah satu cara yang digunakan adalah dengan dikeluarkannya PP No. 41 Tahun 2007 tentang Organisasi Perangkat Daerah, sehingga menarik untuk diteliti. Objek penelitian kali ini membahas mengenai struktur organisasi kelembagaan penanaman modal yang berada di Kota Bandung.

\section{Metode Penelitian}

Penelitian dilakukan dengan menggunakan pendekatan kualitatif. Dengan menggunakan pendekatan ini, peneliti akan menggali lebih dalam mengenai kondisi riil Struktur Organisasi Kelembagaan Penanaman Modal di Kota Bandung. Dengan metode ini maka dapat diidentifikasi model eksisting, untuk kemudian di rekonstruksikan ke dalam model idealnya.

Penelitian ini memperoleh data dengan teknik pengumpulan In-Depth Interview terhadap informan yang dianggap paling mengetahui mengenai Struktur Organisasi Kelembagaan Penanaman Modal di Kota Bandung. Kami himpun data dari sisi SDM, Kelembagaan, dari sisi penelitian dan pengembangan, hingga peraturan perundang-undangan mengenai Struktur Organisasi Kelembagaan Penanaman Modal di Kota Bandung. Selain itu juga melakukan observa- 
Tersedia Online di http://journal.unismuh.ac.id/index.php/otoritas

Otoritas : Jurnal Ilmu Pemerintahan, 6 (2), Oktober 2016, 74

si lapangan, Focus Group Discussion, Studi Literatur, dan Pengumpulan data sekunder.

Data yang diperoleh akan diuji dengan melakukan triangulasi ke semua sumber data yang dianggap terkait dengan permasalahan dan topik penelitian. Selanjutnya akan disajikan secara sistematis dengan deskripsi yang jelas dan terhadap data dan informasi yang diperoleh. Analisis data dilakukan secara deskriptif dengan memetakan dan memaparkan aspek-aspek yang dianalisis secara sistematif. Analisis yang dilakukan bersifat multilevel analysis yang mencakup aspek-aspek di level mikro (persepsi, tanggapan dan opini), meso (organisasional) dan makro (kebijakan).

\section{Hasil dan Pembahasan}

Undang-Undang Republik Indonesia Nomor 25 Tahun 2007 tentang Penanaman Modal mengamatkan bahwa investasi harus menjadi bagian dari penyelenggaraan perekonomian nasional dan ditempatkan sebagai upaya untuk : (1) meningkatkan pertumbuhan ekonomi nasional; (2) menciptakan lapangan kerja; (3) meningkatkan kapasitas dan kemampuan teknologi nasional; dan (4) mendorong pembangunan ekonomi kerakyatan serta mewujudkan kesejahteraan masyarakat dalam suatu perekonomian yang berdaya saing. Untuk itu, Pemerintah Pusat dan Daerah mempunyai tanggung-jawab bersama dalam memberikan stimulan bagi perkembangan sektor riil perekonomian melalui investasi. Selanjutnya dalam Penjelasan Undang-undang Nomor 25 Tahun 2007 tentang Penanaman Modal, dijelaskan bahwa :

"Undang-Undang ini memerintahkan agar Pemerintah meningkatkan koordinasi antar instansi Pemerintah, antar instansi Pemerintah dengan Bank Indonesia, dan antarinstansi Pemerintah dengan Pemerintah Daerah. Koordinasi dengan Pemerintah Daerah harus sejalan dengan semangat otonomi daerah. Pemerintah Daerah bersama-sama dengan instansi atau lembaga, baik swasta maupun Pemerintah, harus lebih diberdayakan lagi, baik dalam pengembangan peluang potensi daerah maupun dalam koordinasi promosi dan pelayanan penanaman modal. Pemerintah Daerah menjalankan otonomi seluas-luasnya untuk mengatur dan mengurus sendiri urusan penyelenggaraan penanaman modal berdasarkan asas otonomi daerah dan tugas pembantuan atau dekonsentrasi. Oleh karena itu, peningkatan koordinasi kelembagaan tersebut harus dapat diukur dari kecepatan pemberian perizinan dan fasilitas penanaman modal dengan biaya yang berdaya saing. Agar memenuhi prinsip demokrasi ekonomi, Undang-Undang ini juga memerintahkan penyusunan peraturan perundang-undangan mengenai bidang usaha yang tertutup dan yang terbuka dengan persyaratan, termasuk bidang usaha yang harus dimitrakan atau dicadangkan bagi usaha mikro, kecil, menengah, dan koperasi."

Dengan diberlakukannya Undangundang Nomor 32 Tahun 2004 tentang Pemerintahan Daerah, dan Undangundang Nomor 33 Tahun 2004 tentang Perimbangan Keuangan Antara Pemerintah Pusat dan Pemerintahan Daerah, maka Pemerintah Kabupaten/Kota diberi kewenangan oleh Pemerintah Pusat untuk melakukan pengembangan sumber daya berdasarkan kewenangan yang diberikan dalam suatu sistem pembagian keuangan yang adil, proporsional, demokratis, transparan, dan efisien dalam rangka pendanaan penyelenggaraan desentralisasi, dengan mempertimbangkan potensi, kondisi, dan kebutuhan daerah, serta besaran pendanaan penyelenggaraan dekonsentrasi dan tugas pembantuan.

Dalam UU No. 32 Tahun 2004 Penanaman Modal merupakan urusan wajib dan menurut PP No. 38 Tahun 2007 salah satu kewenangan pemerintah daerah ada- 
Tersedia Online di http://journal.unismuh.ac.id/index.php/otoritas

Otoritas : Jurnal Ilmu Pemerintahan, 6 (2), Oktober 2016, 75

lah penanaman modal. Undang-Undang Nomor 32 Tahun 2004 tentang Pemerintahan Daerah sebagaimana telah diubah untuk terakhir kali dengan Undang-Undang Nomor 12 Tahun 2008, tiap -tiap daerah mempunyai hak dan kewajiban untuk mengatur dan mengurus sendiri urusan pemerintahan serta berupaya untuk meningkatkan efisiensi dan efektivitas penyelenggaraan pemerintahan dan pelayanan kepada masyarakat Pemerintah Daerah diberikan kewenangan.

Berdasarkan ketentuan Pasal 14 ayat (1) Undang-Undang Nomor 32 Tahun 2004 dijelaskan bahwa urusan yang menjadi kewenangan pemerintahan daerah untuk kabupaten/kota merupakan urusan yang berskala kabupaten/kota terdiri dari urusan wajib dan urusan pilihan. Urusan wajib bagi kabupaten/ kota tersebut antara lain bidang pendidikan, kesehatan, kependudukan, dan lain-lain termasuk didalamnya adalah penanaman modal daerah.

Urusan pemerintahan di bidang penanaman modal merupakan urusan pemerintahan yang wajib diselenggarakan pemerintahan daerah propinsi dan pemerintahan daerah kabupaten/kota, dasar hukumnya diuraikan dalam pasal 7 ayat (2) Peraturan Pemerintah No. 38 Tahun 2007 tentang Pembagian Urusan Pemerintahan antara Pemerintah, Pemerintah Daerah Propinsi dan Pemerintahan Daerah Kabupaten/Kota.

Salah satu kewenangan pemerintah daerah yang disebutkan dalam Peraturan Pemerintah No. 38 Tahun 2007 tentang Pembagian Urusan Pemerintahan antara Pemerintah, Pemerintah Daerah Propinsi dan Pemerintahan Daerah Kabupaten/ Kota adalah Penanaman Modal yang tergambarkan dalam Gambar 1.

Struktur organisasi Bappeda Kota Bandung terdiri dari Kepala Badan, membawahi secretariat yang dipimpin oleh sekretaris Badan, secretariat ini membawahi 3 sub bagian yaitu sub bagian umum dan kepegawaian, sub bagian keuangan, dan sub bagian program, yang masing-masing sub bagian dipimpin oleh Kepala Sub Bagian. Kepala Badan juga membawahi 6 Bidang, yaitu Bidang Perencanaan Tata Ruang, Sarana dan Prasarana, Bidang Perencanaan Ekonomi dan Pembiayaan, Bidang Perencanaan Pemerintahan, Bidang Perencanaan Sosial Budaya dan Kesejahteraan Masyarakat, Bidang Penelitian, Pengembangan, dan Statistik, dan Bidang Penanaman Modal, yang masing-masing Bidang dipimpin oleh Kepala Sub Bidang, dan masingmasing Bidang membawahi 2 Sub Bidang, yang masing-masing dipimpin oleh Kepala Sub Bidang.

Bappeda Kota Bandung ini memiliki Bidang paling banyak diantara BappedaBappeda di Kota/Kab se-Jawa Barat yaitu terdiri dari 6 Bidang. Dalam Peraturan Pemerintah Nomor 41 Tahun 2007 tentang Organisasi Perangkat Daerah, dimana disana disebutkan bahwa Badan ini paling banyak terdiri dari 4 Bidang dan membawahi 2 Sub Bidang yaitu pada pasal 26 ayat 2, sedangkan didalam struktur Bappeda Kota Bandung ini terdiri dari 6 Bidang, ini tentu berseberangan dengan Peraturan Pemerintah Nomor 41 Tahun 2007. Dalam UndangUndang Nomor 32 Tahun 2004, yang sekarang sudah direvisi menjadi UndangUndang Nomor 23 Tahun 2014 tentang Pemerintahan Daerah, dimana disana disebutkan mengenai urusan wajib dan urusan pilihan, dimana salah satu urusan wajib ini adalah penanaman modal, kemudian dalam Peraturan Pemerintah Nomor 38 Tahun 2007 tentang Pembagian urusan antara pemerintah pusat, pemerintah provinsi, dan pemerintah kabupaten/kota, salah satu kewenangan pemerintah daerah adalah dalam bidang penanaman modal, di pemerintahan Kota Bandung, penanaman modal yang merupakan urusan wajib dan salah satu kewenangan pemerintah daerah ditempatkan dalam struktur organisasi 
Tersedia Online di http://journal.unismuh.ac.id/index.php/otoritas

Otoritas : Jurnal Ilmu Pemerintahan, 6 (2), Oktober 2016, 76

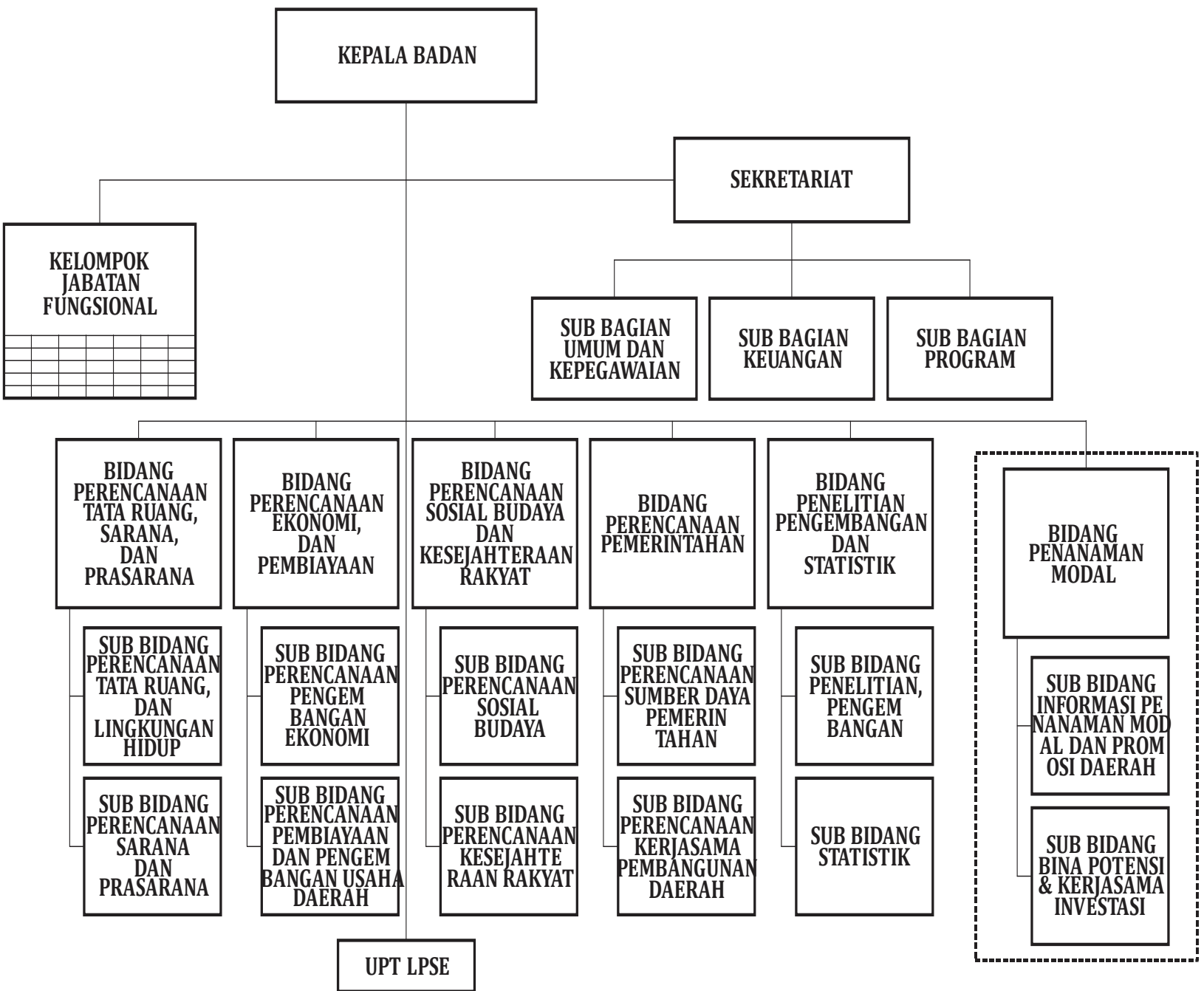

Gambar 1. Struktur kelembagaan penanaman modal di Kota Bandung (Hasil Penelitian, 2016) 
Tersedia Online di http://journal.unismuh.ac.id/index.php/otoritas

Otoritas : Jurnal Ilmu Pemerintahan, 6 (2), Oktober 2016, 77

Bappeda Kota Bandung yaitu pada Bidang Penanaman Modal, ini tentu saja berseberangan dengan UU No. 32 Tahun 2004/ UU No. 23 Tahun 2014 dan Peraturan Pemerintah No. 38 Tahun 2007.

Dalam struktur Pemkot Bandung khususnya pada institusi Bappeda, maka Bidang Penanaman Modal ditempatkan pada posisi yang sentral dalam menumbuhkan penanaman modal di Kota Bandung. Hambatan fungsional pada insitusi Bappeda khususnya Bidang Penanaman Modal turut menjadi faktor yang menghambat kegiatan penanaman modal di Kota Bandung.

Penempatan bidang penanaman modal di dalam struktur organisasi Bappeda Kota Bandung yaitu Bidang Penanaman Modal, di pimpin oleh Kepala Bidang setara dengan eselon III, Bidang penanaman modal di Bappeda Kota Bandung, terdiri dari Sub Bidang Informasi Penanaman Modal dan Promosi Daerah dan Sub Bidang Potensi Kerjasama dan Investasi, hal ini mengakibatkan tidak optimalnya fungsi koordinasi, fungsi pengawasan, dan fungsi pengendalian dalam bidang penanaman modal. Core Business Bappeda adalah perencanaan, sehingga dalam bidang penanaman modal tidak optimal, Bappeda Kota Bandung tidak bisa melakukan pengendalian dan pengawasan terhadap perusahaan asing di Kota Bandung.

Pengendalian dan Pengawasan terhadap penanaman modal asing dan penanaman modal dalam negeri menjadi terhambat, apakah benar penggunaan jumlah tenaga kerja asing di perusahaan sesuai dengan peraturan belum bisa dilakukan, termasuk terhadap setiap penanam modal berkewajiban membuat laporan tentang kegiatan penanaman modal sesuai Undang-Undang No. 25 Tahun 2007 belum bisa dilakukan pengawasan dan pengendalian. Laporan Kegiatan Penanaman Modal (LKPM) adalah laporan secara berkala mengenai perkembangan kegiatan perusahaan dan kendala yang dihadapi penanam modal. LKPM ditujukan untuk memantau realisasi investasi dan produksi. LKPM mencakup kegiatan penanaman modal yang dilakukan perusahaan di setiap lokasi dan bidang usaha investasi, kecuali bidang usaha perdagangan. Bagi perusahaan yang melakukan kegiatan penanaman modal di bidang usaha perdagangan, LKPM cukup berdasarkan lokasi yang telah dinyatakan pada Izin Prinsip.

Bappeda Kota Bandung belum memiliki strategi pemasaran kota untuk menciptakan daya tarik bagi penanaman modal serta daya saing kota sebagai tempat investasi dibandingkan dengan kota atau daerah lain. Belum dimilikinya strategi pemasaran kota untuk Kota Bandung terlihat dari tidak adanya strategi pasar serta program pemasaran kota. Tidak adanya strategi pasar investasi Kota Bandung tercermin dari : belum jelasnya target investasi (usaha) yang diandalkan, tidak tegasnya perumusan diferensiasi Kota Bandung, tidak jelasnya positioning Kota Bandung dalam hal penanaman modal.

Peran jabatan (job role) adalah sejumlah tugas atau peran yang harus dilakukan atau diharapkan dapat dilakukan pada suatu jabatan atau sebuah struktur dalam organisasi. Suatu jabatan dikatakan memiliki hambatan fungsional jika jabatan tersebut tidak atau kurang mampu menunjukkan perannya. Keberadaan dan kejelasan Tugas Pokok dan Fungsi (Tupoksi) yang dimiliki suatu jabatan satu hal yang mutlak, hal lain adalah kemampuan pemegang jabatan untuk menjalankan tupoksinya.

Usaha pemerintah Kota Bandung dalam menumbuhkan penanaman modal tidak akan terlepas dari keterlibatan para stakeholder yang akan membentuk kondisi kota yang ramah investasi. Untuk itu komunikasi dengan para stakeholder menjadi kunci suksesnya, saat ini pemerintah Kota Bandung kurang menjalin komunikasi dengan para stakeholder seperti : komunitas bisnis, komunitas kre- 
Tersedia Online di http://journal.unismuh.ac.id/index.php/otoritas

Otoritas : Jurnal Ilmu Pemerintahan, 6 (2), Oktober 2016, 78

atif kota, dan perguruan tinggi. Kurangnya komunikasi ini juga menjadi hambatan strategis penanaman modal, sebagai akibatnya Pemerintah Kota Bandung kurang memiliki gagasan untuk menciptakan terobosan-terobosan dalam mengembangkan potensi-potensi sumber daya kota atau sekedar memperbaiki infrastruktur kota.

Selain Bapeda, Badan Pelayanan Perijinan Terpadu (BPPT) juga menjadi badan yang memiliki peran yang juga sentral untuk dapat memfasilitasi penanaman modal. Namun pada kenyataannya Badan ini belum menunjukkan fungsi yang optimal dalam pelayanan perizinan usaha di Kota Bandung.

Tidak maksimalnya fungsi dari Bappeda dan BPPT banyak diakibatkan oleh profesionalisme birokrasi pada kegiatan penanaman investasi baru ataupun penciptaan iklim yang kondusif bagi perkembangan bisnis. Hambatan ini berupa masih kurangnya responsiveness dan empathy birokrasi pemerintah kota. Responsiveness dan empathy menyangkut kemampuan dan kesediaan jajaran personalia Pemerintah Kota Bandung untuk bekerja ekstra menjalankan tugas dan fungsinya sesuai jabatan yang dipercayakan kepadanya. Personalia Pemerintah Kota Bandung belum memiliki kualitas sensitifitas dan kreatifitas untuk pemecahan masalah (problem solving) penanaman modal.

Hambatan untuk penanaman modal yang diakibatkan rendahnya profesionalisme birokrasi di Bappeda dan BPPT juga terjadi karena terdapat senjang (gap) antara rumusan tupoksi kedua badan tersebut dengan sebagian perilaku personalia atau pejabatnya. Kedua lembaga ini telah memiliki rumusan yang jelas tentang perannya (job role) seperti yang tercantum dalam struktur Pemkot Bandung, namun pemahaman dan penghayatan dari personalia pada kedua badan ini adalah hal lain.

Ketegasan lingkup kerja Bagian Pe- nanaman Modal pada Bappeda Kota Bandung juga menjadi suatu permasalahan, pada banyak praktik penanaman modal, banyak investor yang melakukan proses penanaman modal tidak melalui Bagian ini. Proses penanaman modal di Kota Bandung dapat dilakukan melalui 'pintupintu' yang lain, misalnya melalui lembaga atau jabatan yang lebih tinggi dalam struktur pemerintahan Kota Bandung. Terjadinya ketidaktegasan atau ambiguity lingkup kerja pada Bagian Penanaman Modal juga menjadi masalah yang akan akan menghambat fungsi Bagian ini secara optimal.

Sementara layanan jajaran Pemkot Bandung yang aktif di bidang perijinan, seperti BPPT dan dinas terkait, juga belum sepenuhnya memberikan pelayanan prima (service excellence) kepada calon investor. Kurangnya responsiveness dan empathy pada personalia BPPT terlihat pada belum dapat diterapkannya standar waktu dan biaya proses pengurusan izin untuk usaha. Pada umumnya pemohon izin untuk usaha baru harus mengeluarkan biaya tambahan atau jangka waktu yang lebih lama untuk memperoleh ijin. Semangat atau paradigma pada pelaksanaan fungsi kerja di BPPT atau Dinas pemberi rekomendasi ijin masih mengidentifikasi lembaganya menjadi badan pelaksana birokrasi perijinan, bukan pelayanan perizinan. Masih kentalnya paradigma ini menjadikan persoalan perizinan menjadi hambatan serius bagi penanaman modal di Kota Bandung.

Oleh karena itu agar kelembagaan penanaman modal di Kota Bandung ini menjadi efektif, maka perlu kiranya Bidang Penanaman Modal tidak lagi menjadi bagian didalam struktur organisasi Badan Perencanaan Pembangunan Daerah Kota Bandung, tetapi dibentuk menjadi Satuan Kerja Perangkat Daerah (SKPD) baru dan berbentuk Dinas Penanaman Modal, hal ini dikarenakan Bidang Penanaman Modal dalam Struktur Organisasi Badan Perencanaan Pembangunan

Copyright (C) 2016, Otoritas : Jurnal Ilmu Pemerintahan, p-ISSN: 2088-3706, e-ISSN: 2502-9320 
Tersedia Online di http://journal.unismuh.ac.id/index.php/otoritas

Otoritas : Jurnal Ilmu Pemerintahan, 6 (2), Oktober 2016, 79

Daerah Kota Bandung memiliki kewenangan yang besar, urusannya besar, volume pekerjaannya besar, tetapi tidak diimbangi dengan jumlah SDM yang ada di Badan Perencanaan Pembangunan Daerah Kota Bandung, selain itu Bidang Penanaman Modal ini merupakan urusan wajib Daerah sesuai dengan Peraturan Pemerintah No. 38 Tahun 2007 tentang Pembagian Urusan Pemerintahan antara Pemerintah, Pemerintah Daerah Propinsi dan Pemerintahan Daerah Kabupaten/ Kota, dan Undang-Undang Nomor 23 Tahun 2014 tentang pemerintahan daerah, dimana urusan wajib dan pilihan di wadahi dalam bentuk Dinas.

\section{Kesimpulan}

Struktur memegang peranan yang sangat penting dalam jalannya organisasi. Struktur memungkinkan sebuah organisasi untuk mencapai tujuan. Apapun organisasinya, organisasi selalu didirikan untuk mencapai tujuan. Ada orientasi yang ingin dicapai dengan berdirinya sebuah organisasi dan orientasi tersebut akan lebih mudah dicapai jika terdapat pembagian kerja yang diimplementasikan dalam sebuah struktur.

Penanaman Modal di Kota Bandung masuk didalam struktur organisasi Bappeda Kota Bandung yaitu Bidang Penanaman Modal, dalam UU No. 32 Tahun 2004 Penanaman Modal merupakan urusan wajib dan menurut PP No. 38 Tahun 2007 salah satu kewenangan pemerintah daerah adalah penanaman modal. Salah satu kewenangan pemerintah daerah yang disebutkan dalam Peraturan Pemerintah No. 38 Tahun 2007 tentang Pembagian Urusan Pemerintahan antara Pemerintah, Pemerintah Daerah Propinsi dan Pemerintahan Daerah Kabupaten/ Kota adalah Penanaman Modal.

Agar kelembagaan penanaman modal di Kota Bandung ini menjadi efektif, maka perlu kiranya Bidang Penanaman Modal tidak lagi menjadi bagian didalam struktur organisasi Badan Perencanaan
Pembangunan Daerah Kota Bandung, tetapi dibentuk menjadi Satuan Kerja Perangkat Daerah (SKPD) baru dan kelembagaannya berbentuk Dinas Penanaman Modal, dengan struktur organisasi didalamnya sesuai dengan Peraturan Pemerintah No. 41 Tahun 2007 memiliki paling banyak 4 Bidang.

\section{Ucapan Terima Kasih}

Penelitian ini tidak terlepas dari dukungan Pimpinan, teman sejawat pada Badan Penelitian, Pengembangan, dan Penerapan IPTEK Provinsi Jawa Barat, atas dukungan dan kebaikan hatinya, saya ucapkan terima kasih.

\section{Daftar Pustaka}

Aris Munanto. 2012. Pengaruh Struktur Organisasi Terhadap Efektivitas Kantor Pertanahan Di Provinsi Bengkulu. Tesis Administrasi Publik Unpad Bandung.

Azwar, Syaifuddin. (2007). Validitas dan Reliabilitas, Yogyakarta: Pustaka Pelajar

Bagozzi, R.P., H. Baumgartner dan Y. Yi. (1992). State versus Action Orientation and the Theory of Reasoned Action: An Application to Coupon Usage, Journal of Consumer Research, 18, 505 - 518

Bennis, Warren \& Mische, Michael. 1996. Organisasi Abad 21, Reinventing melalui Reengineering. Penerjemah : Rachmayanti, Irma Andriani. Jakarta : LPPM.

Bentler, P.M. (1980). Multivariate Analysis with Latent Variabeles: Causal Model, Annual Review of Psychology, 31, 419 - 456

Bungin, HM Burhan. 2005. Metode Penelitian Kualitatif : Komunikasi, Ekonomi, Kebijakan Publik serta Ilmu-Ilmu Sosial Lainnya. Jakarta : Kencana.

Bryman, Alan. 2004. Social Research Meth- 
Tersedia Online di http://journal.unismuh.ac.id/index.php/otoritas

Otoritas : Jurnal Ilmu Pemerintahan, 6 (2), Oktober 2016, 80

od $2^{\text {nd }}$ ed. Oxford : University Press.

Creswell, W. John. 1994. Research Design : Qualitative and Quantitative Approaches. California : Sage Publications, Inc.

Djohanputro, Bramantyo. 2004. Restrukturisasi Perusahaan Berbasis Nilai : Strategi Menuju Keunggulan Bersaing. Jakarta : PPM.

Dumairy, 1997 "perekonomian Indonesia", Erlangga.

Gibson, Ivancevich, Donnely., 1992. Organisasi dan Manajemen : Perilaku, Struktur, Proses. Jakarta : Erlangga.

Guilford, J.P. 1979. Psychometric Methods. New Delhi : Tata McGraw-Hill Publishing Company Limited.

Hammer, Michael \& Chmppy, James. 1995. Rekayasa Ulang Perusahaan (Reengineering The Corporation). Penerjemah : Widodo, Marcus, Prihmito. Jakarta : Gramedia.

Handoko, Hani, Dkk. 2004. Strategi Organisasi. Yogyakarta : Amara Books.

Hasibuan, Malayu S.P. 1999. Organisasi dan Motivasi : Dasar Peningkatan Produktivitas. Jakarta : Bumi Aksara.

Jones, Gareth R. 2007. Organizational Theory, Design and Change. Pearson Prentice Hall, New Jersey.

Kotler, Philip. dan Kevin Lane Keller. 2012. Marketing Management, thirteenrd Edition. Pearson.

Kurniawan, Dedy. 2012. Pengaruh Restrukturisasi Organisasi terhadap Kualitas Pelayanan Sertifikat Tanah di Kantor Pertanahan Kota Depok. Tesis Administrasi Publik Unpad Bandung.

Liliweri, Alo. 1997. Sosiologi Organisasi. Bandung : Citra Aditya Bhakti.
Lovelock, Christopher H . 2001. "Principleof Service Marketing and Management. Second Edition. Prentice Hall

Mankiw, N. Gregory, 2000, “Teori Makroekonomi", Edisi ke-4, Jakarta, erlangga

Mc Gill, GA. 1993. Introduction on Management Study. New York : McMillian.

Miles, Jefrey A. 2012. Management and Organization Theory, John Willey and Sons, San Francisco.

Mintzberg, H. 1979. Organizational Power and Goals in Charless Hofer and Dan Schedel., Strategic Management : A New View of Businesss Policy and Planning. Boston : Little Brown.

Mintzberg, H. 1983. Structure in Five: Designing Effective Organization. Englewood Cliffs, NJ: Prentice Hall.

Nasution, M. A. , S. 1964. Azas-azas Kurikulum, Bandung. Penerbit Terate.

Robbins, Stephen P. 1994. Organization Theory : Structure, Design and Applications. Terjemahan Jusuf Udaya, Teori Organisasi : struktur, desain dan aplikasi. Arcan.

Robbins, Stephen P. 1996. Perilaku Organisasi : Konsep, Kontroversi dan Aplikasi. Alih bahasa Hadyana $\mathrm{Pu}-$ jaatmaka. Jakarta : Prenhallindo.

Robbins, Stephen P., Mary Coulter. 1999. Manajemen. Alih bahasa oleh T. Hermaya. Jakarta : Prenhallindo.

Sedarmayanti. 2000. Restrukturisasi dan Pemberdayaan Organisasi dalam Menghadapi Dinamika Perubahan Lingkungan. Bandung : Mandar Maju. 
Tersedia Online di http://journal.unismuh.ac.id/index.php/otoritas

Otoritas : Jurnal Ilmu Pemerintahan, 6 (2), Oktober 2016, 81

Siagian, Sondang P. 2004. Manajemen Sumber Daya Manusia. Jakarta : Bumi Aksara.

Siagian, Sondang P. 2003. Manajemen Strategik. Jakarta : Bumi Aksara.

Steers, Richard M. 1985. Efektifitas Organisasi. Terjemahan Magdalena Jamin. Jakarta : Erlangga.

Sudjana. 1992. Metoda Statistik. Jakarta : BPFE.

Susilowati, Rahayu. 2003. Restrukturisasi Organisasi Dinas Daerah Dalam Menciptakan Kualitas Layanan Publik (Studi Pada Dinas Sosial dan Pemberdayaan Perempuan Kota Bandar Lampung). Tesis Ilmu Sosial Unpad Bandung.

Todaro, Michael P, 2000, "Economic Development", 7th edition, Pearson Education Limited

Winardi. 2003. Teori Organisasi dan Pengorganisasian. Jakarta : Rajagrafindo

Zeithaml, Valerie A and mary Bitner, 1996. Service Marketing. Mc Graw-Hill Education (India). Pvt Limited

Zulfakri. 2002. Pengaruh Restrukturisasi Organisasi Dinas Kesejahteraan Sosial terhadap Kualitas Pelayanan Publik Kota Palembang. Thesis Ilmu Sosial Unpad Bandung.

Peraturan Daerah Kota Bandung No. 6 Tahun 2001 tentang Pembentukan dan susunan organisasi lembaga teknis daerah Kota Bandung.

Peraturan Daerah Kota Bandung No. 12 Tahun 2007 tentang Pembentukan dan susunan organisasi lembaga teknis daerah Kota Bandung.
Peraturan Daerah Kota Bandung No. 08 Tahun 2008 tentang Rencana Pembangunan Jangka Panjang Daerah (RPJPD) Tahun 2005 2025.

Peraturan Daerah Kota Bandung No. 09 Tahun 2009 tentang Rencana Pembangunan Jangka Menengah Daerah (RPJM) Tahun 2009 2013.

Peraturan Daerah Kota Bandung No. 12 Tahun 2009 tentang Perubahan atas Peraturan Daerah Kota Bandung Nomor 12 Tahun 2007 tentang Pembentukan dan susunan organisasi lembaga teknis daerah Kota Bandung.

Peraturan Pemerintah Republik Indonesia Nomor 8 Tahun 2008 tentang Tahapan, Tata Cara Penyusunan, Pengendalian, dan Evaluasi Pelaksanaan Rencana Pembangunan Daerah.

Rencana Strategis Bappeda Kota Bandung $2009-2013$.

Surat Edaran Bersama Menteri Negara Perencanaan Pembangunan Nasional/Kepala Bappenas dan Menteri Dalam Negeri No. 008/ M.PPN/01/2007/05/264A/SJ tentang Petunjuk Teknis Penyelenggaraan Musrenbang Tahun 2007.

Undang-Undang Republik Indonesia No. 25 Tahun 2004 tentang Sistem Perencanaan Pembangunan Nasional. Masyarakat Desa, Perspektif Orang daerah dan Orang Desa di Enam Desa Jawa-Bali, Jakarta: Forum Pengembangan Partisipasi Masyarakat. 